\title{
Pelatihan sebagai pemicu kedisiplinan karyawan survey pada karyawan CU Lantang Tipo KC Balai Berkuak
}

Teresia Wiliantara

STIE Indonesia Pontianak

\begin{abstract}
Abstrak
Tujuan - Penelitian ini bertujuan untuk mencari hubungan antara pemberian pelatihan pada karyawan dengan tingkatkeisiplinan pada karywan CU Lantang Tipo KC Balai Berkuak.

Desain/Methodologi/Pendekatan - Sampel yang digunakan adalah sampel jenuh. Metode yang digunakan adalah deskriptif kuantitatif.

Temuan penelitian - Hasil penelitian didapat bahwa karyawan menjadi sangat disiplin karena adanya pelatiha berkala yang baik dan peaturan perusahaan yang tegas
\end{abstract}

Kata kunci: Disiplin, kinerja, pelatihan

Jenis artikel: Artikel penelitian

\section{Training as a trigger for employee discipline employee survey at $\mathrm{CU}$ Lantang Tipo KC Balai Berkuak}

\begin{abstract}
Purpose, - This study aims to find a relationship between providing training to employees and the level of discipline in employees of CU Lantang Tipo KC Balai Berkuak.

Design/Methodology/Approach - The sample used is a saturated sample. The method used is descriptive quantitative

Research findings - The results showed that employees became very disciplined because of good periodical training and firm company regulations.
\end{abstract}

Keywords Discipllin, performance, training

Paper type: Research Paper

Jurnal Manajemen Sains dan Organisasi

Vol 2, No 3, 2021 pp. $211-217$

P-2685-4724; E-2798-9577
Published in the Jurnal Manajemen sains dan Organsasi. Published by FEB UPR Publishing Limited. This article is published under the Creative Commons Attribution (CC BY 4.0) licence. Anyone may reproduce, distribute, translate and create derivative works of this article (for both commercial and non-commercial purposes), subject to full attribution to the original publication and authors. 


\section{Pendahuluan}

Sumber daya manusia merupakan suatu hal yang sangat penting yang harus dimiliki dalam upaya mencapai tujuan organisasi atau perusahaan. Menurut sumber daya manusia kompeten yang dimiliki semangat dan kedisiplinan tinggi menjalankan tugas dan tanggungjawabnya baik untuk individu maupun tujuan operasional. Setiap manajemen dituntut untuk mengembangkan cara-cara yang menarik dalam pelaksanaan kedisiplinan kerja agar organisasi atau perusahaan mampu dalam usaha meningkatkan produktivitas karyawan lebih baik lagi dengan memberikan pelatihan. Mendisiplinkan karyawan memang sangat dibutuhkan pada suatu perusahaan. Hal ini diperlukan untuk meningkatkan produktivitas kerja karyawan serta tujuan perusahaan dapat tercapai. Kedisiplinan diterapkan kepada karyawan agar tertib dalam bekerja dan patuh terhadap aturan yang ada pada perusahaan serta karyawan tidak bertindak sesuka hati terhadap aturan yang berlaku.

Kedisiplinan merupakan sifat dari pertanggung jawaban individu untuk melaksanakan segala sesuatunya dengan tepat waktu. Jika tidak disiplin, maka pekerjaan yang diembannya akan menjadi terbengkalai. Adapun Pelatihan yang diberikan untuk Staf CU Lantang Tipo Kantor Cabang Balai Berkuak dibùtuhkan untuk meningkatkan kualitas serta kuantitas kerja agar tercapainya target kerja. Pelatihan juga diberikan agar Standar Pelayanan tetap terjaga dengan baik untuk mencapai Visi dan Misi lembaga. Pelatihan yg diberikan menyesuaikan kebutuhan masing masing staf, supaya implementasi dari tujuan pelatihan bisa diterapkan dengan maksimal di Kantor Cabang

Berikut adalah Pelatihan yg diberikan bagi Staf CU Lantang Tipo KC Balai Berkuak :

1. Pelatihan Teknik Standar Pelayanan Prima

Pelatihan Teknik Standar Pelayanan Prima bertujuan agar staf bisa mengetahui atau memahami terkait standar pelayanan yg dibutuhkan untuk memberikan kepuasan dalam pelayanan kepada anggota.

Teknik Standar Pelayanan Prima meliputi Tata Krama dalam pelayanan seperti Senyum, Salam dan Sapa serta terkait penampilan standar staf yg diwajibkan agar berpenampilan rapi dan menarik sesuai standar kebijakan yg sudah diatur dalam kebijakan lembaga.

2. Pelatihan Training for Trainer

Pelatihan Training of Trainer bertujuan untuk menjadikan seorang staf siap menjadi Trainer (Pengajar) baik secara teknis maupun non teknis. Pendekatan yang tepat dalam ToT dilakukan melalui pembelajaran berdasarkan pengalaman sebagai Trainer.

3. Pelatihan Penanganan Kredit Lalai

Pelatihan Teknik Penanganan Kredit Lalai dibutuhkan agar staf bisa mengatur strategi serta teknik teknik jitu yang termuat pada pola kebijakan lembaga yang dibutuhkan dalam proses penanganan kredit lalai.

4. Pelatihan Marketing

Pelatihan Marketing bertujuan agar staf bisa lebih memahami terkait pemasaran kredit yg menjadi nafas utama pengelolaan aset lembaga. Pelatihan Marketing dibutuhkan supaya staf menguasai teknik dalam proses penawaran kredit kepada anggota potensial.

5. Pelatihan Etos Kerja

Pelatihan Etos Kerja bertujuan agar staf bisa mengevaluasi terkait dengan etos atau semangat kerja sebagai seorang aktivis Credit Union. Etos Kerja dibutuhkan dalam pengelolaan lembaga agar bisa berkembang lebih baik dan mampu berkompetisi dalam tujuan memajukan anggota.

\section{Landasan Teori}

Menurut Ekosiswoyo dan Rachman (2000), kedisiplinan hakikatnya adalah sekumpulan tingkah laku individu maupun masyarakat yang mencerminkan rasa ketaatan, kepatuhan, yang didukung oleh kesadaran untuk menunaikan tugas dan kewajiban dalam rangka pencapaian tujuan. Menurut Fayhoni (2006), kedisiplinan dapat diartikan bila mana pegawai selalu datang dan pulang pada tepat waktu yang ditentukan oleh kepala manejer, pimpinan dari masing-masing 
instansi.

Menurut Sastrohadiwiryo (2003) secara khusus tujuan disiplin kerja para pegawai, antara lain: Agar para pegawai menepati segala peraturan dan kebijakan ketenagakerjaan maupun peraturan dan kebijakan organisasi yang berlaku, baik tertulis maupun tidak tertulis, serta melaksanakan perintah manajemen dengan baik. Pegawai dapat melaksanakan pekerjaan dengan sebaik-baiknya serta mampu memberikan pelayanan yang maksimum kepada pihak tertentu yang berkepentingan dengan organisasi sesuai dengan bidang pekerjaan yang diberikan kepadanya. Pegawai dapat menggunakan dan memelihara sarana dan prasarana, barang dan jasa organisasi dengan sebaik-baiknya. Para pegawai dapat bertindak dan berpartisipasi sesuai dengan norma-norma yang berlaku pada organisasi.

Pegawai mampu menghasilkan produktivitas yang tinggi sesuai dengan harapan organisasi, baik dalam jangka pendek maupun jangka panjang. Manfaat dari adanya kedisiplinan yang telah ditetapkan dalam sebuah perusahaan adalah dapat menumbuhkan kepedulian sesama karyawan, menumbuhkan kepekaan akan tanggungjawab yang di emban, menumbuhkan percaya diri, menumbuhkan keakraban dan mengajarkan keteraturan.

Menurut Tulus Tu'u dalam Indah Puji Hartatik (2014, p.186) yang mengemukakan beberapa fungsi disiplin, yaitu:

a) Menata kehidupan bersama

Disiplin berfungsi mengatur kehidupan bersama, dalam suatu kelompok tertentu atau masyarakat. Dengan begitu kehidupan yang terjalin antara individu satu dengan lainnya menjadi lebih baik dan lancar.

b) Membangun kepribadian

Disiplin juga dapat membangun kepribadian seorang pegawai. Lingkungan yang memiliki disiplin tinggi sangat berpengaruh terhadap kepribadian seseorang. Lingkungan organisasi yang memiliki keadaan yang tenang, tertib, dan tentram, sangat berperan dalam membangun kepribadian yang baik.

c) Melatih kepribadian

Disiplin merupakan sarana untuk melatih kepribadian pegawai agar senantiasa menunjukan kinerja yanng baik. Sikap, prilaku dan pola kehidupan yang baik dan berdisiplin terbentuk melalui satu proses yang panjang. Salah satu proses untuk membentuk kepribadian tersebut dilakukan melalui latihan, latihan dilaksanakan antar pegawai, pimpinan, dan seluruh personal yang ada diorganisasi tersebut.

d) Hukuman

Disiplin yang disertai ancaman sanksi atau hukuman sangat penting, karena dapat memberikan dorongan kekuatan untuk menaati dan mematuhinya. Tanpa ada nya ancaman hukuman, dorongan ketaatan dan kepatuhan dapat menjadi lemah, serta motivasi untuk mengikuti aturan yang berlaku menjadi berkurang.

e) Menciptakan lingkungan konduktif

Fungsi disiplin adalah membentuk, sikap, perilaku, dan tata kehidupan berdisiplin di dalam lingkungan kerja, sehingga tercipta suasana tertib dan teratur dalam pelaksanaan pekerjaan.

Menurut Darmawan (2013) produktivitas kerja adalah ukuran yang menunjukkan pertimbangan antara input dan output yang dikeluarkan perusahaan serta peran tenaga kerja yang dimiliki persatuan waktu. Dewan Produktivitas Nasional Indonesia telah merumuskan definisi produktivitas secara lengkap yaitu sebagai berikut (Umar Husein, 2002): produktivitas pada dasarnya merupakan suatu sikap mental yang selalu mempunyai pandangan bahwa mutu kehidupan hari ini lebih baik dari kemarin dan hari esok lebih baik dari hari ini.

Secara umum produktivitas mengandung pengertian perbandingan antara hasil yang dicapai (output) dengan keseluruhan sumber daya yang digunakan (input). Produktivitas mempunyai dua dimensi, yaitu efektivitas yang mengarah pada pencapaian unjuk kerja yang maksimal yaitu pencapaian target yang berkaitan dengan kualitas, kuantitas, dan waktu. Yang kedua efisiensi yang berkaitan dengan upaya membandingkan input dengan realisasi penggunaannya atau bagaimana pekerjaan tersebut dilaksanakan. 
Menurut Anoraga (2004), ada faktor-faktor yang mempengaruhi produktivitas kerja karyawan adalah sebagai berikut:

a) Motivasi

Pimpinan Organisasi perlu mengetahui motivasi kerja dari anggota organisasi karyawan. Dengan mengetahui motivasi itu maka pimpinan dapat mendorong karyawan lebih baik.

b) Pendidikan

Pada umumnya seseorang mempunyai pendidikan lebih tinggi akan mempunyai produktivitas kerja yang lebih baik, hal demikian ternyata merupakan syarat yang penting dalam meningkatkan produktivitas kerja karyawan. Tanpa bekal pendidikan, mustahil orang akan mudah dalam mempelajari hal-hal yang bersifat baru dalam cara atau suatu sistem.

c) Disiplin Kerja

Disiplin kerja adalah sikap kejiwaan seseorang atau kelompok yang senantiasa berkehendak untuk mengikuti atau mematuhi segala peraturan yang telah ditentukan. Disiplin kerja mempunyai hubungan yang sangat erat dengan motivasi, kedisiplinan dengan suatu latihan antar alin dengan bekerja menghargai waktu dan biaya akan memberikan pengaruh positif terhadap produktivitas kerja karyawan.

d) Keterampilan

Keterampilan banyak pengaruhnya terhadap produktivitas kerja karyawan. Keterampilan karyawan dalam perusahaan dapat ditingkatkan melalui training, kursus-kursus dan lainlain.

e) Sikap dan Etika Kerja

Sikap seseorang atau kelompok orang dalam membina hubungan yang serasi, selaras dan seimbang di dalam kelompok itu sendiri maupun dengan kelompok lain. Etika dalam hubungan kerja sangat penting karena dengan tercapainya hubungan seimbang antara perilaku dalam proses produksi akan meningkatkan produktivitas kerja.

f) Gizi dan Kesehatan

Daya tahan tubuh seseorang biasanya dipengaruhi oleh gizi dan makanaan yang didapat, hal itu mempengaruhi kesehatan karyawan, dengan semua itu akan berpengaruh terhadap produktivitas kerja karyawan.

g) Kompensasi

Penghasilan yang cukup berdasarkan prestasi kerja karyawan karena semakin tinggi prestasi karyawan maka akan semakin besar prestasi yang diterima. Dengan itu maka akan memberikan semangat kerja tiap karyawan untuk memacu prestasi sehingga produktivitas kerja karyawan akan tercapai.

h) Lingkungan kerja dan iklim kerja

Lingkungan kerja dari karyawan termasuk hubugan kerja antara karyawan, hubungan dengan pimpinan, suhu serta lingkungan penerangan dan Universitas Sumatera Utara 15 sebagainya. Hal ini sangat penting untuk mendapatkan perhatian dari perusahaan karena sering karyawan enggan bekerja , karena tidak ada kekompakan dalam kelompok kerja atau ruang kerja yang tidak menyenangkan. Hal ini mengganggu kerja karyawan.

i) Teknologi

Dengan adanya kemajuan teknologi yang meliputi peralatan yang semakin otomatis dan canggih akan mendapat dukungan tingkat produksi dan mempermudah manusia dalam melaksanakan pekerjaan.

j) Sarana produksi

Faktor-faktor produksi harus memadai dan saling mendukung dalam proses produksi.

k) Jaminan Sosial

Perhatian dan pelayanan perusahaan kepada setiap karyawan, menunjang kesehatan dan keselamatan. Dengan harapan agar karyawan semakin bergairah dan mempunyai semangat untuk kerja.

1) Manajemen

Dengan adanya manajemen yang baik maka karyawan akan berorganisasi dengan baik, 
dengan demikian produktivitas kerja akan tercapai.

m) Kesempatan berprestasi

Setiap orang dapat mengembangkan potensi yang ada dalam dirinya, dengan diberikan kesempatan berprestasi, maka karyawan akan meningkatkan produktivitas

\section{Metode}

Dalam penelitian ini yang digunakan adalah metode deskriptif dimana penulis menggambarkan suatu keadaan secara objektif sebagaimana kenyatan yang ditemui dengan mengambil objek peneliti pada kantor CU. Lantang Tipo KC. Balai Berkuak Dalam penelitian ini penulis menggunakan metode penelitian survei,dimana penulis dalam melakukan penelitian langsung mengadakan pengamatan dan kemudian dianalisis sesuai dengan keadaan sebenarnya. Dalam rangka mengumpulkan data atau fakta pada penulisan ini maka penulis menggunakan teknik pengumpulan data sebagai berikut:

a) Teknik Komunikasi Langsung

b) Teknik Komunikasi Tidak Langsung

c) Teknik Studi Dokumen

Populasi dalam penelitian ini adalah seluruh karyawan CU Lantang Tipo berjumlah 11 orang di KC. Balai Berkuak. Pengambilan sampel dilakukan dengan menggunakan sampel jenuh, jumlah sampel dalam penelitian ini adalah sebanyak 11 orang dari jumlah populasi. Pengumpulan data primer dilakukan dengan melakukan survey langsung ke CU Lantang Tipo KC. Balai Berkuak sebagai objek penelitian.

\section{Hasil penelitian}

Berdasarkan karakteristik umur responden menunjukkan bahwa responden yang berumur kurang dari 25 tahun tidak ada, responden yang berumur 26-35 tahun sebanyak 10 orang dengan persentase sebesar $91 \%$, dan responden yang berumur lebih dari 35 tahun sebanyak 1 orang dengan persentase sebanyak $9 \%$ berdasarkan karakteristik umur responden sebagian besar responden berumur antara 26-35 tahun yaitu sebesar 91\%.

Berdasarkan karakteristik responden jenis kelamin dapat diketahui bahwa karyawan terbanyak pada CU Lantang Tipo KC. Balai Berkuak adalah laki-laki yaitu sebanyak 7 dari 11 dengan persentase sebanyak 64\%, sedangkan yang paling sedikit adalah perempuan yaitu sebanyak 4 dari 11 responden dengan persentase sebanyak 36\%. Sebagian besar responden yang ada adalah responden berjenis kelamin laki-laki dengan persentase sebesar $64 \%$.

Berdasarkan karakteristik responden lama bekerja menunjukkan bahwa responden lama bekerja kurang dari 2 tahun sebanyak 3 orang dengan persentase sebanyak $28 \%$, responden lama bekerja 3-5 tahun sebanyak 4 orang dengan persentase sebanyak $36 \%$ dan responden lebih dari 5 tahun sebanyak 4 orang dengan persentase sebanyak $36 \%$

Berdasarkan tanggapan responden mengenai ketepatan waktu dapat diketahui 100\% responden merasa bahwa selalu datang tepat waktu sebelum jam kerja dimulai dengan persentase dan $81 \%$ merasa bahwa tidak pernah meninggalkan tempat kerja tanpa izin dari atasan Berdasarkan tanggapan responden mengenai ketaatan terhadap peraturan pada dapat diketahui $100 \%$ karyawan merasa telah melaksanakan semua peraturan yang ditetapkan oleh CU Lantang Tipo KC. Berdasarkan tanggapan responden mengenai tanggung wajab kerja dapat diketahui mengenai Saya melaksanakan pekerjaan dengan penuh tanggung jawab dengan persentase sebesar 100\% responden setuju, mengenai Saya bertanggung jawab terhadap hasil pekerjaan yang ditugaskan oleh atasan dengan persentase sebesar 100\% responden setuju. Berdasarkan tanggapan responden mengenai Tugas dan Kewajiban dapat diketahui $100 \%$ karyawan merasa sanggup menjalankan tugas lapangan apabila ditugaskan oleh atasan dan $100 \%$ karyawan merasa hadir tepat waktu.

Lingkungan kerja adalah suatu hal yang sangat penting dan perlu diperhatikan terutama bagi sebuah perusahaan ataupun kantor yang memiliki banyak karyawan yang bekerja.lingkungan kerja inilah ialah yang berpengaruh terhadap pekerja dalam melaksanakan 
tugasnya.Kehidupan manusia tidak terlepas dari berbagai keadaan lingkungan sekitarnya, antara manusia dan lingkungan terdapat hubungan yang sangat erat.merupakan suatu kondisi pekerjaan untuk memberikan suasana dan situasi kerja karyawan yang nyaman dalam pencapaian tujuan yang diinginkan oleh suatu lembaga maupun perusahaan.

Berdasarkan tanggapan responden mengenai Lingkungan Kerja dapat diketahui mengenai Saya selalu menjaga sikap yang baik didalam lingkungan kerja dengan persentase sebesar $100 \%$ responden setuju, mengenai Pegawai yang berperilaku baik maka akan nyaman bagi lingkungan kerja dengan persentase sebesar $100 \%$ responden setuju, mengenai Saya sudah menjaga kebersihan lingkungan kerja pada CU Lantang Tipo KC. Balai Berkuak dengan persentase sebesar $100 \%$ responden setuju, mengenai Lingkungan kerja yang bersih dapat menciptakan suasana kerja yang nyaman dan damai dengan persentase sebesar $100 \%$ responden setuju. Berdasarkan tanggapan responden mengenai kemampuan, dapat diketahui mengenai Tugas dan tanggung jawab diberikan sesuai dengan kemampuan saya dengan persentase sebesar 100\% responden setuju, mengenai Saya bekerja dengan bersungguhsungguh agar tidak terjadi kesalahan dengan persentase sebesar 100\% responden setuju.

Peningkatan kualitas sumber daya manusia dalam rangka meningkatkan produktivitas kerja pegawai dapat dilakukan dengan berbagai cara, misalnya melalui kegiatan pendidikan dan latihan (diklat),melanjutkan pendidikan ke tingkat yang lebih tinggi. Dengan meningkatkan produktivitas kerja karyawan maka, hasil yang di peroleh akan tercapai sesuai dengan rencana perusahaan. Berdasarkan tanggapan responden mengenai meningkatkan hasil yang dicapai, dapat diketahui mengenai Terkadang saya merasa jenuh terhadap pekerjaan yang saya tangani dengan persentase sebesar $9 \%$ responden tidak setuju dan dengan persentase sebesar 91\% responden sangat tidak setuju, mengenai Saya bekerja sesuai dengan program kerja dengan persentase sebesar 100\% responden setuju.

Berdasarkan tanggapan responden mengenai semangat kerja pada tabel 3.10 tersebut, dapat diketahui mengenai Saya tidak pernah mengeluh dan merasa berat terhadap beban pekerjaan yang menjadi tanggung jawab saya dengan persentase sebesar $100 \%$ responden setuju. Berdasarkan tanggapan responden mengenai pengembangan diri, dapat diketahui mengenai Saya selalu mengikuti pelatihan yang diadakan oleh CU Lantang Tipo KC. Balai Berkuak untuk meningkatkan keahlian dengan persentase sebesar $100 \%$ responden setuju. Berdasarkan tanggapan responden mengenai mutu, dapat diketahui mengenai Saya selalu berusaha untuk meningkatkan kualitas kerja dengan persentase sebesar $100 \%$ responden setuju.

Peringatan melanggar aturan adalah sistem pelaksanaan kedisiplinan yang diterapkan oleh CU. Lantang Tipo KC. Balai Berkuak adalah memberi peringatan baik lisan maupun tulisan. Peringatan lisan berupa teguran langsung oleh atasan kepada karyawan, seorang atasan akan berbicara langsung kepada karyawan yang melanggar aturan dan memberi nasehat agar karyawan yang melanggar aturan tidak menggulangi kesalahan yang sama. Sedangkan peringatan tulisan adalah berupa surat peringatan dan surat peringatan yang diterapkan oleh CU Lantang Tipo KC Balai Berkuak adalah surat peringatan 1, 2, dan 3. Hal ini agar karyawan yang melanggar aturan tidak semena-mena dengan aturan yang telah di tetapkan dan membuat efek jera kepada karyawan yang sering melanggar aturan. Dengan begitu para karyawan CU Lantang Tipo KC Balai Berkuak menerapkan pelatihan bagi karyawan agar dapat berkembang dan meningkatkan skill mereka. Hal ini didukung dengan data kuesioner bahwa dengan persentase sebesar $100 \%$ responden setuju saya selalu mengikuti pelatihan yang diadakan oleh CU. Lantang Tipo KC. Balai Berkuak untuk meningkatkan keahlian.

\section{Daftar Pustaka}

CU. Lantang Tipo KC. Balai Berkuak. 2021. www.culantangtipo.com

Sugiyono.2018:57. Definisi Variabel Penelitian http://repository.unpas.ac.i d/46078/5/BAB\%20III\%20PDF.pdf

Mangkunegara. 2013:129 Dalam Mulyadi. 2015:49 Bentuk Disiplin Kerja 
repository.ump.ac.id/7547/3/BAB II_DENI ARISKA_MANAJEMEN'18.pdf

Usman, $\quad$ Nurdin. $2002^{-}$Pengertian Implementasi https://www.pelajaran.co.id/2017/15/pengertian-implementasi-menurut-paraahli.html

Fathoni. 2006. Definisi Kedisiplinan https://www.seputarpengetahuan.co.id/2017/08/20pengertian-disiplin-menurut-para ahli.html

Hasibuan. 2010:128. Pengertian http://eprints.dinus.ac.id/17585/1/jurnal_14891.pdf

Produktivitas Karyawan

Sastrohadiwiryo. 2003. Tujuan Kedisiplinan https://www.e-jurnal.com/2014/03/tujuandisiplin-kerja.html

Tu'u, Tulus dan Indah Puji Hartatik. 2014, p.186. Fungsi Kedisiplinan http://repo.darmajaya.ac.id/129/3/17.\%20BAB\%20II.pdf

Husein, Umar. 2002. Definisi Produktivitas Kerja http://etheses.uinmalang.ac.id/1839/5/08410052_Bab_2.pdf

Anoraga. 2004. Faktor Yang Mempengaruhi Produktivitas Kerja Karyawan repository.usu.ac.id/bitstream/handle/123456789/57385/Chapter II

Sugiyono. 2018:48. Pengertian Metode http://repository.unpas.ac.id/46078/5/BAB\%20III\%20PDF.pdf

Morrisan. 2012;19. Pengertian Populasi https://rumusbilangan.com/pengertian-populasimenurut-para-ahli/

Sugiyono. 2008:118. Pengertian Sampel. https://www.weschool.id/pengertian-sampelmenurut-para-ahli-beserta-definisinya-lengkap/

$\begin{array}{llll}\text { Sugiyono. } & 2012 ; 73 . & \text { Pengertian } & \text { Sampel }\end{array}$ http://repository.unpas.ac.id/30110/6/BAB\%20III\%20Lanjutan.pdf

Mardalis. 2005. Sistem Perhitungan Persentase. Jakarta: Bumi Aksara 